\title{
Sounding the Alarm: The Council of Europe As the Guardian of the Rule of Law in Contemporary Europe*
}

\author{
Jörg Polakiewicz and Julia Katharina Kirchmayr
}

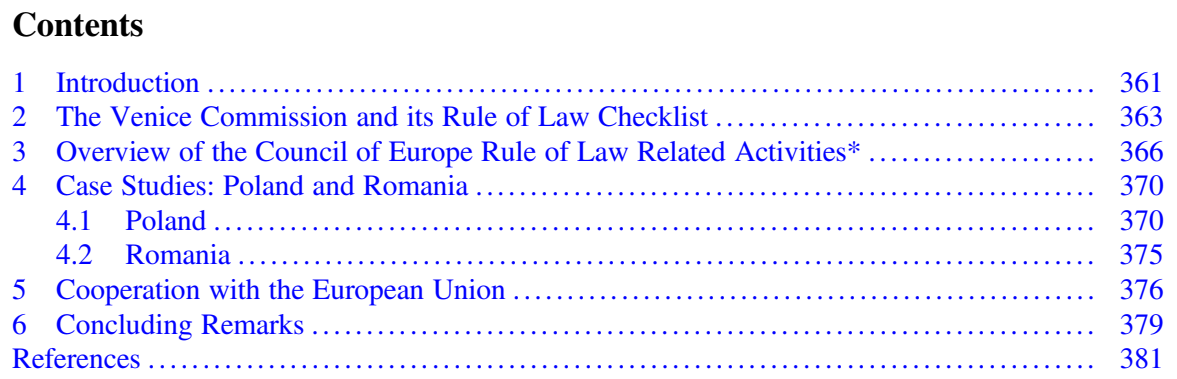

\section{Introduction}

The Council of Europe was founded upon the Rule of Law as one of its three core principles. This transpires from the preamble of the Council's Statute and the requirements for membership, as enshrined in Article 3 where "every member of the Council of Europe must accept the principles of the Rule of Law [emphasis added] and of the enjoyment by all persons within its jurisdiction of human rights

\footnotetext{
*This submission was completed on 23 August 2019 and thereby only reflects upon the developments up and until this date.

J. Polakiewicz $(\triangle)$

Europainstitut of the University of Saarbrücken, Saarbrücken, Germany

Directorate of Legal Advice and Public International Law (Legal Adviser), Council of Europe, Strasbourg, France

e-mail: Jorg.Polakiewicz@coe.int
}

J. K. Kirchmayr

European Commission, Brussels, Belgium

e-mail: Julia.Kirchmayr@ec.europa.eu 
and fundamental freedoms, and collaborate sincerely and effectively in the realisation of the aim of the Council."

Respect for the Rule of Law is a precondition for the accession of States to the Organisation. The Rule of Law is of the upmost importance for the Council, so much that if a member State were to consistently fail to uphold this principle, it may trigger the application of Article 8 which would not only provide for the suspension of a State's right to representation, but also its eventual expulsion if the systematic violations continued to persist. The relevant Committee of Minister's decisions require a mere two-thirds majority (as defined by Article 20 (d) of the Statute). ${ }^{2}$

The Parliamentary Assembly disposes of a range of measures in the context of its own monitoring procedure. Based on the procedure to challenge the credentials of national delegations, it may choose to suspend the voting and participatory rights of a delegation. ${ }^{3}$ These powers have been subject to criticism on both political and legal grounds. ${ }^{4}$ Following the adoption of the decision by the Committee of Ministers at its 129th Session (Helsinki, 17 May 2019) on "A shared responsibility for democratic security in Europe - Ensuring respect for rights and obligations, principles, standards and values", the Assembly modified its sanctions regime. Henceforth, the members' right to vote, to speak and to be represented in the Assembly and its bodies shall not be suspended or withdrawn in the context of a challenge to or reconsideration of the credentials of these members. ${ }^{5}$ Should a member State continue to persistently disrespect its commitments, the Assembly may address a recommendation to the Committee of Ministers requesting it to take action in accordance with the provisions of Articles 7 and 8 of the Statute. Both organs are currently in the process of setting up, in addition to the existing procedures, a joint reactionary procedure to serious violations of the Organisation's fundamental principles and values, including the Rule of Law, which could be triggered by the Parliamentary Assembly, the Committee of Ministers or the Secretary General.

So far, no member State has ever been sanctioned for showing a blatant disregard for the Rule of Law. Attempts to open 'monitoring procedures' in respect to Hungary $^{6}$ and Malta ${ }^{7}$ failed in April 2013 and June 2019. Yet, on 24 April 2017, the Assembly chose to reopen a monitoring procedure regarding Turkey citing

\footnotetext{
${ }^{1}$ Statute of the Council of Europe, ETS No 001, London, 5 May 1949.

${ }^{2}$ Ibid.

${ }^{3}$ See Evans and Silk (2013).

${ }^{4}$ See 'Role and responsibilities of the Council of Europe's statutory organs with special emphasis on the limitation of membership rights' DLAPIL 18/2018 of 25 September 2018.

${ }^{5}$ Parliamentary Assembly Resolution 2287 (2019) of 25 June 2019.

${ }^{6}$ Parliamentary Assembly, PACE Committee Recommends Monitoring of Hungary, 25 April 2013.

${ }^{7}$ A motion presented in the context of 'Daphne Caruana Galizia's assassination and the rule of law in Malta and beyond: ensuring that the whole truth emerges' (Report by P Omtzigt, doc. 14906) failed, but Resolution 2293 (2019) was adopted and states inter alia that "the rule of law in Malta is seriously undermined by the extreme weakness of its system of checks and balances."
} 
"serious concerns" related issues.

This contribution addresses the Council of Europe's various mechanisms designed to strengthen the Rule of Law before examining our cooperation with the European Union and in particular, the European Commission, who in light of the serious breaches of the Rule of Law has initiated infringement proceedings against Poland and referred two cases to the European Court of Justice ${ }^{9}$ in addition to asking the Council of the European Union to adopt a decision under Article 7 of the Treaty on European Union. ${ }^{10}$

\section{The Venice Commission and its Rule of Law Checklist}

The 'European Commission for Democracy through Law', otherwise known as the Venice Commission is an independent consultative body established through an enlarged Council agreement. The Commission has 61 members, the 47 Council of Europe member States and 14 other countries including Algeria, Brazil, Chile, Costa Rica, Israel, Kazakhstan, the Republic of Korea, Kosovo, Kyrgyzstan, Morocco, Mexico, Peru, Tunisia and the US. The Commission has in the past been publicly referred to as the "custodian of constitutional probity all over Europe.",

For more than 20 years, the Venice Commission has supported and advised individual countries on the Rule of Law in order to strengthen democratic institutions and protect human rights. As one of its primary objectives, the Commission promotes the Rule of Law as a basic feature of the European constitutional order through recommendations and opinions on draft constitutions and legislation. The Venice Commission can be seized by the Committee of Ministers, the Parliamentary Assembly, the Congress of Local and Regional Authorities of Europe, the Secretary General or by a participating State, international organisation or body to provide an opinion. ${ }^{12}$ It may also carry out research on its own accord; prepare studies and draft guidelines, laws and international agreements. ${ }^{13}$ Its flexible and ad-hoc character allows the Venice Commission to react swiftly to threats posed to the Rule of Law and ensures the Commission's relevance, in the midst of unfolding crises as the most

\footnotetext{
${ }^{8}$ Parliamentary Assembly, PACE reopens monitoring procedure in respect of Turkey, 25 April 2017.

${ }^{9}$ CJEU, Case C-619/18 Commission v Poland, ECLI:EU:C:2019:531. CJEU, Case C-192/18 Commission v Poland ECLI:EU:C:2019:529.

${ }^{10}$ European Commission, Rule of Law: European Commission acts to defend judicial independent in Poland, 20 December 2017.

${ }^{11}$ Gardner (6 April 2017).

${ }^{12}$ Council of Ministers, Resolution (2002) 3, Article 3(2).

${ }^{13}$ Ibid, Article 3 (1).
} 
recent events in Hungary, Poland, Romania, the Ukraine and Turkey, have illustrated.

In 2007, the Parliamentary Assembly called upon the Venice Commission to assist in the offering of further reflections on the Rule of Law in Europe. Following thorough deliberations, the Venice Commission published a 'Report on the Rule of Law' in 2011, in which it sought to identify a consensual definition of the Rule of Law in order to assist "international organisations and both domestic and international courts in interpreting and applying this fundamental value" 14 and distinguish the Rule of Law from a rule by law. The report concluded that, despite a variety of opinions a consensus, regarding the core formal and substantive elements that compromise the Rule of Law could, nonetheless, be found.

During its plenary session in March 2016, the Venice Commission adopted its 'Rule of Law Checklist' a practical, accessible and user-friendly instrument intended to be used by a broad breadth of actors, including national authorities, international and non-governmental organisations, academics and ordinary citizens. Designed as a precise enough tool to allow for the application of the Rule of Law principles in an objective, in-depth, and transparent manner, the Checklist is, when applied, meant to benefit from the broad involvement of interested stakeholders. ${ }^{15}$

The Checklist is neither exhaustive nor final; rather, it aims to cover a series of core elements of the Rule of Law whilst taking into account the diversity of Europe's legal systems and traditions. ${ }^{16}$ The Checklist translates five principles of the Rule of Law (legality; legal certainty; prevention of abuse of power; equality before the law and non-discrimination; and access to justice) into concrete questions with the intention of applying these to evaluate and assess the country-specific circumstances of its members. It also offers concrete examples of particular challenges with which the Rule of Law is, at times confronted with, such as claims of corruption and conflicts of interest ${ }^{17}$ or the collection of personal data and surveillance. ${ }^{18}$

In order to understand the practical value of the Rule of Law Checklist, one should consider the following example: Access to Justice. Access to Justice is an essential requirement to ensure that we do not find ourselves living in a world dominated by lex imperfecta and yet, it remains a broad, perhaps even vague principle and should thus be divided into two sub-principles: (a). independence and impartiality and (b). fair trial. Both of these sub-principles are still quite general in their nature and thus require further elaboration. The principle of independence and impartiality for example, includes inter alia the independence of the judiciary and of individual judges, the impartiality of the judiciary, the autonomy of the prosecution service and the independence and impartiality of the Bar. Whilst the

\footnotetext{
${ }^{14}$ Venice Commission, Venice Commission Report on the Rule of Law, 4 April 2011, paragraph 3.

${ }^{15}$ Ibid, paragraph 24 .

${ }^{16}$ For more information on the Rule of Law Checklist, see also Drzemczewski (2018), pp. 179-184.

${ }^{17}$ Venice Commission Report on the Rule of Law, supra (note 16), paragraph 114.

${ }^{18} \mathrm{Ibid}$, paragraph 117.
} 
abovementioned components are, at their core still 'principles' they are nonetheless much more precise than the umbrella terms: independence and impartiality.

The Checklist includes a number of more detailed questions regarding the independence of the judiciary: ${ }^{19}$ one general question and a number of specific follow-up questions regarding the independence of individual judges: ${ }^{20}$

a) General: Are there sufficient constitutional and legal guarantees for the independence of individual judges? ${ }^{21}$

b) Specific: Are judicial activities subject to the supervision of higher courts (outside the appeal framework), court presidents, the executive or other public bodies? Does the Constitution guarantee the right to a competent judge ("natural judge pre-established by law")? Does the law clearly determine which court is competent? Does it set rules to solve any conflicts of competence? Does the allocation of cases follow an objective and transparent criteria? Is the withdrawal of a judge from a case excluded (other than in cases where a recusal by one of the parties or by the judge him/herself has been declared)?

These questions aim to decipher the country-specific status of the Rule of Law, once they are answered, it becomes easier to identify possible shortcomings and subsequently, (hopefully!) remedy them.

With the adoption of the Rule of Law Checklist in March 2016, the Venice Commission established "one of the few widely accepted conceptual frameworks for the Rule of Law in Europe." 22 The Checklist has been formally endorsed by the Committee of Ministers in September 2016 and a month later, by the Congress of Local and Regional Authorities. The Parliamentary Assembly of the Council of Europe also approved the Rule of Law Checklist during its plenary session in October 2017. ${ }^{23}$ The resolution foresees a systematic use of the Checklist by the Assembly, in particular in relation to the preparation of reports by the Committee on Legal Affairs and Human Rights and the Committee on the Honouring of Obligations and Commitments by Member States of the Council of Europe (Monitoring Committee). ${ }^{24}$ Furthermore, the Parliamentary Assembly invited national parliaments, governmental bodies and ministries, regional and international organisations, and civil actors to refer to the Checklist when contemplating legislative reform and carrying out their respective activities. ${ }^{25}$

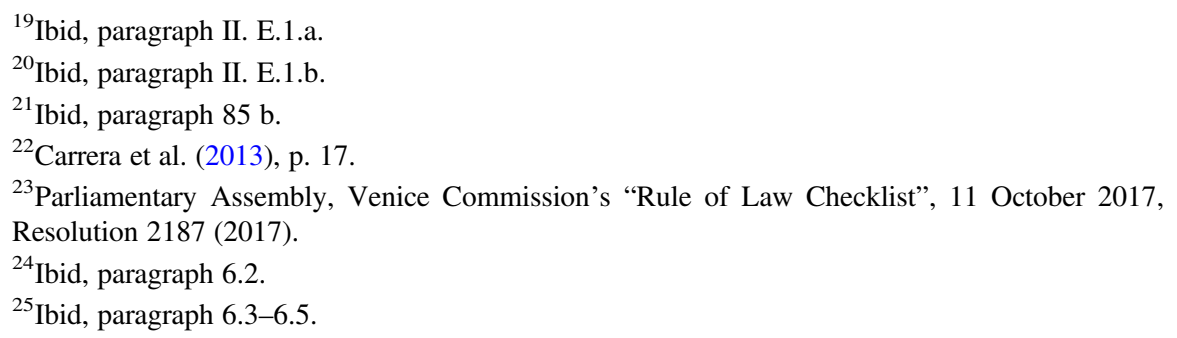


According to the former UN Secretary-General Ban Ki-moon, "the Rule of Law is like the rule of gravity." ${ }^{26}$ Gravity is, however a scientifically defined concept which describes a universally applicable, naturally existing phenomenon. The Rule of Law, by contrast, is a set of principles describing ideals that every society must freely choose to adopt and adapt to their precise juridical, historical, political and social contexts; thus the effective realisation of the Rule of Law very much depends upon the commitment of civil society. Moreover, the diversity of Europe's legal systems and traditions, must be taken into account when discussing the application of the Venice Commission's Checklist.

Legal discourse at a European level rarely reaches the same breadth and depth as at national level which, as Dieter Grimm observed, takes place in a much closer context of participation and responsibility. ${ }^{27}$ International judges enjoy, in a certain sense, a greater level of freedom than their national counterparts and thus try to counterbalance this by respecting national judicial identities. This acknowledgment is also reflected in the justifications for the ECtHR (The European Court of Human Rights)'s recourse to the margin of appreciation and the principle of subsidiarity. A good example of this is the 'measuring' of the 'fairness' of a procedure or system, a task which can only be accomplished with reference to its particular context and through the weighing of different factors which feed into this complex assessment. In order to fully appreciate the significant role played by the national context for this assessment, one may look towards the election procedure of judges in different member States. Whilst the election of judges by citizens is a well-established practice in Switzerland, ${ }^{28}$ the same approach would be unimaginable in a country with a recent history of interethnic warfare, like Bosnia and Herzegovina.

\section{Overview of the Council of Europe Rule of Law Related Activities $^{29 *}$}

According to the European Convention on Human Rights, the Rule of Law famously forms part of "the common heritage" very soul of the Convention.

The Court used the concept of "prééminence du droit" or "rule of law" for the first time in Golder v. United Kingdom in February 1975, ${ }^{31}$ basing its interpretation of

\footnotetext{
${ }^{26}$ GA/11290, 'World Leaders Adopt Deceleration Reaffirming Rule of Law as Foundation for Building Equitable State Relations, Just Societies', 24 September 2012.

${ }^{27}$ Grimm (2016), p. 171.

${ }^{28}$ Though not uncontested, see Lübbe-Wolff (2019), Available via https://verfassungsblog.de/ richterwahlen-in-der-schweiz-wo-liegt-das-problem/. Accessed 26 August 2019.

${ }^{29}$ For more information please see Polakiewicz and Sandvig (2016), pp. 115-134.

${ }^{30}$ Preamble of the European Convention on Human Rights, Rome 4 November 1950.

${ }^{31}$ ECtHR, Golder v. United Kingdom, Judgment of 21 February 1975, Application no. 4451/70.
} 
Article 6 of the Convention (right to a fair trial) on the reference to the Rule of Law in the Convention's Preamble. It emphasised that this principle should not merely be seen as a "more or less rhetorical reference", 32 devoid of relevance for those interpreting the Convention. One of the reasons for why the signatory Governments decided to "take the first steps for the collective enforcement of certain of the rights stated in the Universal Declaration"33 was their profound belief in the Rule of Law. Since then, the Rule of Law has become a guiding principle for the Court which "inspires the whole Convention" 34 by being "inherent in all the Articles of the Convention." 35 In this context, the Court has offered further clarification on a number of key themes which underpin the Rule of Law, including: (1). the separation of powers, (2). the role of the judiciary, (3). impunity, (4). a tribunal established by law, (5). sufficiently accessible and foreseeable law, (6). the scope of legal discretion, (7). nullum crimen sine lege and nulla poena sine lege, (8). legal certainty, (9). the execution of final domestic judgments, (10). equality before the law, (11). the judicial control of the executive, (12). positive obligations of the state in the form of procedural requirements and safeguards, (13). the right of access to a court, (14). the right to an effective remedy, and finally (15). the right to a fair trial.

The Court has emphasised that democracy is inseparably linked to the Rule of Law, the concept implying the existence of a separation of powers, institutional guarantees for an independent and impartial judiciary, as well as the judicial oversight of the executive. ${ }^{36}$ Already in 2002, the Court itself noted that "the notion of separation of powers between the executive and the judiciary has assumed growing importance in the case-law of the Court." ${ }^{, 37}$ This principle is also of relevance with regard to the appointment and selection of judges, whilst the executive and legislative branches may be involved in the appointment, the procedure must be free from undue pressure and interference. ${ }^{38}$

In the case of Baka v. Hungary, the Court recognised the growing importance which international and more specifically, the Council of Europe's legal instruments, case law and bodies attach to procedural fairness in cases concerning the removal and dismissal of judges. ${ }^{39}$ Regarding legal certainty, the Court in Brumărescu v. Romania found that "one of the fundamental aspects of the rule of law is the

\footnotetext{
${ }^{32}$ Ibid, paragraph 30 .

${ }^{33}$ Ibid, paragraph 34 .

${ }^{34}$ ECtHR, Engel and Others v. the Netherlands, Judgement of 8 June 1976, Application no. 5100/ $71 ; 5101 / 71 ; 5102 / 71 ; 5354 / 72 ; 5370 / 72$, paragraph 69.

${ }^{35}$ ECtHR, Amuur v. France, Judgment of 25 June 1996, Application no. 19776/92, paragraph 50.

${ }^{36}$ Steiner (2016), p. 154.

${ }^{37}$ ECtHR, Stafford v. the United Kingdom, Grand Chamber Judgment of 28 May 2002, Application no. 46295/99, paragraph 78 .

${ }^{38}$ See the overview over relevant case-law in the Background Document to the 2018 Judicial Seminar at the Court entitled 'The Authority of the Judiciary', available at: https://www.echr.coe. int/Documents/Seminar_background_paper_2018_ENG.pdf.

${ }^{39}$ ECtHR, Baka v. Hungary, Grand Chamber Judgment of 23 June 2016 Application no. 20261/12, paragraph 172.
} 
principle of legal certainty, which requires, inter alia, that where the courts have made a final determination of an issue, their ruling should not be called into question." 40 More recently, the Court in Guðmundur Andri Ástráðsson addressed at length the principle of the separation of powers and judicial independence and impartiality, specifying that "the Court places emphasis on the importance in a democratic society governed by the rule of law of securing the compliance with the applicable rules of national law in the light of the principle of the separation of powers." 41

The right of access to a court, fair trial and an effective remedy were similarly further elaborated upon by the Court within its growing body of case law. The Court established the basis for the principle of the right of access to a court in the abovementioned case of Golder, when it held that in order to give effect to the procedural guarantees contained within Article 6 of the Convention, the right of access to a court must be provided for. ${ }^{42}$ In Sunday Times Strasbourg not only underlined the fundamentality of public confidence in the judiciary and the importance of the Court's role as a guarantor of justice for the Rule of Law, but also emphasised that the principle implies the need for a fair trial. ${ }^{43}$ In relation to the remedy required by Article 13, the Court perceived an effective remedy as "either [to] prevent the alleged violation or its continuation or prove adequate redress for any violation that had already occurred." 44 The Court has also elaborated upon what it understands as the criteria for the phrase 'prescribed by law': "[f]irstly, the law must be adequately accessible... Secondly, a norm cannot be regarded as a "law" unless it is formulated with sufficient precision to enable the citizen to regulate his conduct: he must be able - if need be with appropriate advice - to foresee, to a degree that is reasonable in the circumstances, the consequences which a given action may entail." 45

The ECtHR thus has, and continues to hold, a crucial function in safeguarding the Rule of Law by fleshing out this principle through relevant case-law.

Furthermore the Committee of Ministers' supervision of the execution of ECtHR judgments constitutes as an invaluable source of information as to the efforts made by member States to remedy both individual and systemic ECHR violations, including those related to the Rule of Law. The Secretary General's annual report on the 'State of Democracy, Human Rights and the Rule of Law in Europe' similarly draws upon the involvement of the Committee of Ministers. In 2017, the Committee was

\footnotetext{
${ }^{40}$ ECtHR, Brumărescu v. Romania, Grand Chamber Judgment of 28 October 1999, Application no. 28342/95 Reports, paragraph 61.

${ }^{41}$ ECtHR, Guðmundur Andri Ástráðsson, Judgment of 12 March 2019, Application no. 26374/18, paragraph 122.

${ }^{42}$ ECtHR, Amuur v. France, supra (note 37) paragraph 72.

${ }^{43}$ ECtHR, Sunday Times v. United Kingdom (No.1), Judgement of 26 April1979, Application no. 6538/74, paragraph 55 .

${ }^{44}$ ECtHR, Kudla v. Poland, Judgment of 26 October 2000, Application no. 30210/96, paragraph 158.

${ }^{45}$ Ibid, paragraph 49 .
} 
asked to examine a report entitled 'Populism - How strong are Europe's checks and balances' which takes the Venice Commission's Rule of Law Checklist into account. Chapter 1, for instance, emphasised that efficient, impartial and independent judiciaries "are the cornerstone of any functioning system of democratic checks and balances. They are the means by which powerful interests are restrained, according to the laws of the land. They guarantee that all individuals, irrespective of their backgrounds, are treated equally before those laws." ${ }^{46}$ As a follow-up to this second report, which had identified the lack of judicial independence in several European countries as being one of the most serious challenges to a democratic society, the Committee of Ministers adopted the 'Plan of Action on Strengthening Judicial Independence and Impartiality' with the intention of implementing it within the next 5 years (by April 2021). ${ }^{47}$

Apart from the Council of Europe's statutory organs and the Venice Commission, there are various other technical bodies dealing with, in one way or another Rule of Law related issues. In particular, one must mention the Commission for the Efficiency of Justice (CEPEJ), the Consultative Council of European Judges (CCJE) and the Consultative Council of European Prosecutors (CCPE) ${ }^{48}$

The CEPEJ was established to improve the efficiency and functionality of justice in the member States. Through its work, the CEPEJ strengthens the mutual confidence between judicial professionals and promotes the public service of justice. Furthermore, the CEPEJ's evaluation of judicial systems, through the analysis and collection of quantitative and qualitative data offers a reference point for the execution of judicial reforms across Europe. The CEPEJ's work provides a deeper understanding of the day-to-day functioning of courts, the main trends evidenced by the evolution of judicial systems with a view of improving the quality, fairness and efficiency of the public service of justice. In a nutshell, the CEPEJ provides the fertile soil necessary for the Rule of Law to flourish within the judicial and civil fabric of member States.

The work undertaken by the CCJE and CCPE incorporates the perspectives of serving judges and prosecutors throughout Europe. In 2016, the two bureaus drew a comprehensive review of the challenges for judicial independence and impartiality, in which they jointly recognised the public perception of corruption within the justice system to be one of the most serious challenges for the maintenance of public trust and confidence in the independence and impartiality of judges and prosecutors. ${ }^{49}$

\footnotetext{
${ }^{46}$ Report of the Secretary General of the Council of Europe, 'State of Democracy, Human Rights and the Rule of Law' 2017, page 15.

${ }^{47}$ Committee of Ministers, Plan of Action on Strengthening Judicial Independence and Impartiality, $\mathrm{CM}(2016) 36$ final.

${ }^{48}$ For more information on this topic, see Drzemczewski (2018), pp. 184-198.

${ }^{49}$ Consultative Council of European Judges, Challenges for judicial independence and impartiality in the member States of the Council of Europe SG/Inf(2016)3, 15 January 2016, paragraphs 310 and 313.
} 
Let us not forget that the effective realisation of fundamental values, such as democracy and the Rule of Law depend upon a number of institutional actors, women and men, taking ownership and enforcing these at a national level. It is for this reason, that the cooperative activities which assist member States in their efforts to adapt legislation, practices and institutions to European standards are so vital for the realisation of these values.

The Council of Europe's judicial reform projects aim to assist governments in putting into place laws and practices to address the outcomes and findings of ECtHR's judgments, Venice Commission opinions, CEPEJ reports, Committee of Minister's recommendations as well as the standards developed by the CCJE and the CCPE. The Council of Europe is currently managing projects in the Eastern Partnership countries, the Western Balkans as well as in Turkey, Latvia, Slovakia, Kazakhstan, Kosovo, Morocco, Tunisia and Jordan. These projects seek to address judicial self-governance, time management, the role and status of the legal professionals (judges, prosecutors and lawyers), access to justice and the delivery of legal aid.

\section{Case Studies: Poland and Romania}

\subsection{Poland}

The Council of Europe has closely been following the events transpiring in Poland, concerning the government's plans to reform the Constitutional Tribunal and the National Council of the Judiciary. Over the last few years, Poland has adopted more than thirteen laws which aim to transform the judicial system and have had a far-reaching impact upon the Constitutional Tribunal, the Supreme Court, the ordinary courts, the National Council for the Judiciary, the prosecution service and lastly the National School of Judiciary. In a recent public address, the First President of the Supreme Court of Poland, described the reform package as a "coup d'état against the structure of one of the most important State institutions ... not with the armed force or the paramilitary troops but 'only' by misusing legal institutions." ${ }^{50}$

In March 2016, the Venice Commission issued an opinion at the request of the Polish Minister of Foreign Affairs, in which it underlined the crucial role assumed by an effectively functioning Constitutional Court in order for a State to be governed by the tenets of the Rule of Law. As regards to the amendments adopted on 22 December 2015, the Commission concluded that the different measures included therein, especially in their combined effect, would slow down the work of the Constitutional Tribunal and render it ineffective.

\footnotetext{
${ }^{50}$ Professor Dr. M. Gersdorf, Address by the Frist President of the Supreme Court on the reforms of the judiciary in Poland, 22.12.2017.
} 
The Venice Commission was also severely critical of the new composition of the Tribunal, as the Draft Act of the National Council of the Judiciary (NCJ) would alter the election method of the judicial members to allow for the Sejm to elect a total of 15 members, thus skewing the balance of power and effectively politicising the body. ${ }^{51}$ As for the Prime Minister's refusal to publish the Constitutional Tribunal's judgement of 9 March 2016 on the constitutionality of the Act, the Commission held that "a refusal to publish... .would not only be contrary to the Rule of Law, such a unprecedented move would further deepen the constitutional crisis triggered by the election of judges ... not only the Polish Constitution but also European and international standards require that judgments of a Constitutional Court be respected." 52

On 14 October 2016, the Venice Commission published a second Opinion in relation to the Act on the Constitutional Tribunal, in which it examined whether its previous recommendations on the effective functioning and independence of the Constitutional Tribunal had been respected by the Government when it adopted the revised text of the Act. The Commission found that "individually and cumulatively, these shortcomings show that instead of unblocking the precarious situation of the Constitutional Tribunal, the Parliament and Government continue to challenge the Tribunal's position as the final arbiter of constitutional issues and attribute this authority to themselves." 53

The Venice Commission also examined the new Act on the Constitutional Tribunal which entered into force on the 16 August 2016, despite the judgment given by the Polish Constitutional Tribunal which had annulled several provisions of the Act. In its most recent opinion, published in December 2017, the Commission chose to address the merging of the Office of the Public Prosecutor General with that of the Minister of Justice, noting that “...the Minister has a vested interest in the court proceedings, and, at the same time, has important powers vis-à-vis the courts and individual judges." 54

Following a letter by the Chairman of the National Council of the Judiciary of Poland in April 2017, the CCJE urgently adopted an opinion on the Draft Act on the NCJ and certain other acts, underlining that the Draft Act was in a number of respects, incompatible with the European standards on judicial independence. ${ }^{55}$

\footnotetext{
${ }^{51}$ Venice Commission Opinion on the Act on the Constitutional Tribunal, 14 October 2016, paragraph 19.5 .

${ }^{52}$ Ibid, paragraph 143.

${ }^{53}$ Venice Commission Opinion on the Act on the Constitutional Tribunal, supra (note 53), paragraph 128.

${ }^{54}$ Venice Commission Opinion on The Draft Act, Amending The Act On The National Council Of The Judiciary, On The Draft Act Amending The Act On The Supreme Court, Proposed By The President Of Poland And On The Act On The Organisation Of Ordinary Courts, 8-9 December 2017, paragraph 99.

${ }^{55}$ Consultative Council of European Judges, Opinion of the CCJE Bureau following the request of the Polish National Council of the Judiciary to provide an opinion with respect to the Draft Act of 23 January 2017, latest amended on 3 March 2017, amending the Act of 12 May 2011 on the Polish
} 
The CCJE Bureau issued a second statement in July 2017 stating that it "deeply regretted the adoption by the Polish Parliament of the Act on the Polish National Council of the Judiciary." ${ }^{56}$ In September 2017, the President of Poland proposed a revised version of the Draft Acts on the NCJ and the Supreme Court, for which a second CCJE opinion was requested. Once more the CCJE concluded that the amendments proposed "would jeopardize the independence of a body whose main purpose is to guarantee judicial independence in Poland. The new draft does not in any way change this." ${ }^{, 57}$ In November 2017, the CCJE released a statement regarding the "critical situation affecting the rule of law and independence of the judiciary in Poland." 58

In May 2017, the Parliamentary Assembly's Monitoring Committee issued an information note on 'The functioning of democratic institutions in Poland' in which it voiced its concerns regarding the "political and constitutional crisis" 59 following the 2015 parliamentary elections and the new government's subsequent reform plans for the Constitutional Tribunal and the judiciary. The Monitoring Committee asked the Venice Commission to prepare an opinion on the amendments to the law regarding the NCJ, the Act on the Supreme Court, and the Organisation of Ordinary Courts and their compatibility with the relevant European standards on the Rule of Law, democracy and best practices. The Venice Commission found that even the new Proposal for the election of members of the judiciary to the NCJ by a three-fifths majority was "still at odds with the European standards"60 as the "proposed reform will lead to a NCJ dominated by political nominees." ${ }^{61}$ With regard to the Draft Act on the Supreme Court, which foresaw the creation of two new chambers for the hearing of disciplinary cases against Supreme Court judges and other "extraordinary appeals" and another chamber, for the hearing of electoral and other public law disputes, the Venice Commission concluded that despite slight improvements the

National Council of the Judiciary and certain other acts, 7 April 2017, CCJE-BU(2017)5REV, paragraph 26-30.

${ }^{56}$ Consultative Council of European Judges, Opinion of the request of the Polish National Council of the Judiciary to provide an opinion with respect to the Draft Act of September 2017 presented by the President of Poland amending the Act on the Polish National Council of the Judiciary and certain other acts, 12 October 2017, CCJE-BU(2017)9REV, paragraph 5.

${ }^{57}$ Ibid, paragraph 15 .

${ }^{58}$ Consultative Council of European Judges, Statement of the CCJE as regards the situation on the independence of the judiciary in Poland, 10 November 2017, CCJE(2017)9.

${ }^{59}$ Parliamentary Assembly, The functioning of democratic intuitions in Poland, 9 May 2017, AS/Mon(2017)14, paragraph 3.

${ }^{60}$ Venice Commission Opinion on The Draft Act, Amending The Act On The National Council Of The Judiciary, On The Draft Act Amending The Act On The Supreme Court, Proposed By The President Of Poland And On The Act On The Organisation Of Ordinary Courts, supra (note 56), paragraph 24 .

${ }^{61}$ Ibid. 
draft still raised concerns in relation to its "compliance with ... European standards.",62

The Act also lowered the age of retirement for a significant number of currently sitting judges and intends to involve parliamentarians in the proceedings of the Extraordinary Chamber, which possesses the power to review the final and legally binding judgements issued by the other chambers of the Court (even some five orduring the transitional period-20 years after the judgment has been made!). ${ }^{63}$ The Commission maintained that this restructuring would establish a hierarchical formation of "courts within the court," a practice not foreseen for by the Polish Constitution. Moreover, according to the Draft the composition of these two new chambers could, almost completely be determined by the President of the Republic thus "making electoral judges particularly vulnerable to political influence"64 which "creates a serious risk for the functioning of Polish democracy." ${ }^{\circ 5}$ As to the Draft's proposal for the lowering of the retirement age of judges and the provisions which enable the extension of tenure beyond the retirement age at the discretion of the President of the Republic, the Commission questioned these practices, arguing that they would undermine the "security of tenure and the independence of the SC [Supreme Court] in general.",66

The Venice Commission criticized the introduction of an Extraordinary Chamber which in effect may "reopen any case decided in the country ... on virtually any ground ... it means that no judgment in the Polish system will ever be 'final' anymore. ${ }^{, 67}$ It is difficult to reconcile the proposed mechanism with the fundamental principles of the Rule of Law, including res judicata, legal certainty and non-retroactivity. In relation to the powers of the President of the Republic vis-à-vis the Supreme Court, the Commission concluded that the "proposed reform, if implemented, will not only threaten the independence of the judges of the SC [Supreme Court], but also create a serious risk for the legal certainty and enable the President of the Republic to determine the composition of the chamber dealing with the politically particularly sensitive electoral cases." 68 The Venice Commission came to the conclusion that the combined effect of the draft acts and their respective proposals allow the Polish legislative and executive authorities to severely and capaciously intrude upon the administration of justice, thus threatening judicial independence and the Rule of Law. ${ }^{69}$

In 2018, the Council of Europe's Group of States against Corruption (GRECO) published its first ever ad-hoc procedure report, as a response to the "exceptional

\footnotetext{
${ }^{62}$ Ibid, paragraph 34.

${ }^{63}$ Ibid, paragraph 53.

${ }^{64}$ Ibid, paragraph 53.

${ }^{65}$ Ibid, paragraph 43.

${ }^{66}$ Ibid, paragraph 48.

${ }^{67}$ Ibid, paragraph 58.

${ }^{68}$ Ibid, paragraph 89.

${ }^{69}$ Ibid, paragraph 129.
} 
circumstances" and "serious violations" of anti-corruption standards. ${ }^{70}$ GRECO stressed that "several basic principles of the judicial system had been affected in such a critical way and to such an extent that the assessment made in GRECO's Fourth Round Evaluation Report on Poland in 2012 as far as it concerns corruption prevention in respect of judges is no longer pertinent in crucial parts.",71

On 8 March 2018, the Polish government published a White Paper on the Reform of the Polish Judiciary, in order to "explain that the criticism of the reforms is unfounded, but primarily to clear any doubts our European partners may have about the rule of law in Poland." 72 The Paper was sharply criticised by the First President of the Supreme Court for including "distorted and even untrue information which must be corrected." ${ }^{73}$ Similarly, in its response to the Government's White Paper, the Polish Judges Association 'Iustitia' emphasised that the information the White Paper relied upon was "presented in an extremely biased manner, and does not paint a truthful image of the Polish judicial system in the European context." ${ }^{, 74}$ In particular, Iustitia denounced the practice of 'cherry-picking', that is the "drawing of comparisons with selected elements forming part of more complex mechanisms and legal institutions, without regard for their normative environment." 75 The Association concluded that the reforms stipulated in the White Paper "have led to a change in the system of justice and the erosion of guarantees for the independence of the judiciary" ${ }^{, 76}$ and furthermore, that this change was made "without changing the letter of the Constitution.",77

\footnotetext{
${ }^{70}$ Council of Europe's Group of States against Corruption, 'Poland: Judicial reforms violate anticorruption standards, say Council of Europe experts' (Press Release, 29 March 2018) https://www. coe.int/en/web/greco/-/poland-judicial-reforms-violate-anti-corruption-standards-say-council-ofeurope-experts last accessed 23 August 2019.

${ }^{71}$ Council of Europe's Group of States against Corruption, Ad hoc Report on Poland, 19-23 March 2018, Greco-AdHocRep(2018)1, paragraph 57.

${ }^{72}$ The Chancellery of the Prime Minister, White Paper on the Reform of the Polish Judiciary, 7 March 2018, 5.

${ }^{73}$ Professor Dr. M. Gersdorf, Opinion on the White Paper on the Reform of the Polish Judiciary, 16 March 2018, page 1.

${ }^{74}$ Iustitia Polish Judges Association, The Response of the Polish Judges Association 'Iustitia' To The White Paper on the Reform of the Polish Judiciary Presented to the European Commission by the Government of the Republic of Poland, Warsaw 2018, page 9.

${ }^{75}$ Ibid, page 28.

${ }^{76} \mathrm{Ibid}$, page 104

${ }^{77}$ Ibid.
} 


\subsection{Romania}

The Venice Commission and GRECO have also adopted a number of opinions and recommendations regarding the reforms initiated by the Romanian government. ${ }^{78}$ GRECO has expressed its criticism of a series of proposed amendments to the Romanian justice system, including to the criminal justice system, which if viewed alone but especially in the face of the current political climate are likely to undermine the independence of the Romanian judiciary, weaken the public's confidence, and impair the effectiveness of the criminal justice system and the fight against corruption. Their opinions and recommendations ${ }^{79}$ pay tribute to the core concepts that underpin the Rule of Law, including:

- the legislative process should be inclusive and transparent involving effective consultations of all stakeholders and meaningful discussions (which are impossible if the process is excessively fast and non-transparent);

- emergency ordinances and expedited procedures should be the exception, not the rule;

- the principles of legal clarity and certainty and in particular the principle of res judicata must be respected;

- not only judges, also the prosecution service and individual prosecutors should enjoy some independence from interference by the government;

- judges and prosecutors are entitled to freedom of expression; a reasonable balance needs to be struck between the degree to which judges may be involved in society and the need for them to be and to be seen as independent and impartial in the discharge of the duties;

- judges and prosecutors must not be prevented from engaging in debates about the adequate functioning of the justice system; fear of sanctions may have a chilling effect which is detrimental to society as a whole;

- corruption leads to arbitrariness and abuse of powers; it undermines the very foundations of the Rule of Law;

- effectively preventing and sanctioning corruption-related acts are vital anticorruption measures and obligations under Council of Europe conventions against corruption to which Romania is a party.

While GRECO and the Venice Commission acknowledge the need to reform the judiciary and prosecution services, in order to adapt it where necessary to new challenges and realities, such important reforms should not be rushed through Parliament, but be based on an inclusive, vetted procedure. In a state governed by the Rule of Law, it is important to play by the rules, and not with the rules.

\footnotetext{
${ }^{78}$ Council of Europe's Group of States against Corruption, Follow- up Report to the Ad hoc Report on Romania, 17-21 June 2019, Greco-AdHocRep(2019)1.

${ }^{79}$ All opinions and recommendations can be found at the Venice Commission's https://www. venice.coe.int/webforms/events/ and GRECO's https://www.coe.int/en/web/greco websites.
} 
The Council of Europe will continue to monitor developments in Poland and Romania. The Secretary General and the Council's various other bodies remain at the disposal of the national authorities to provide further assistance if so requested.

\section{Cooperation with the European Union}

The 2007 Memorandum of Understanding between the Council of Europe and the European Union recognises the Rule of Law as a priority for matters of common interest and encourages both institutions to commit to the development of common standards to promote "a Europe without dividing lines." ${ }^{80}$ In particular, it provides that:

[t]he Council of Europe and the European Union will endeavour to establish common standards thus promoting a Europe without dividing lines, without prejudice to the autonomy of decision. Bearing this in mind, legal co-operation should be further developed between the Council of Europe and the European Union with a view to ensuring coherence between Community and European Union law and the standards of Council of Europe conventions. This does not prevent Community and European Union law from adopting more far-reaching rules. ${ }^{81}$

The three pillars of our "strategic partnership" namely political dialogue, cooperation projects and legal cooperation have led to collaborations "of unprecedented intensity." 82

It was against this background that the the 'Council of the European Union's Conclusions on Fundamental Rights and the Rule of Law' emphasised the importance of "mak[ing] full use of existing mechanisms and cooperate with other relevant EU and international bodies, particularly with the Council of Europe, in view of its key role in relation to promotion and protection of human rights, democracy and the Rule of Law, in order to avoid overlaps." 83

Referring specifically, to proposals which called for a EU Framework on the Rule of Law to be established, the Committee of Ministers stressed in February 2014 that it "fully supports the efforts deployed by the Secretary General, who has intensified his political consultations with the EU institutions, emphasising in particular the message that a possible future EU framework should take into account the instruments and expertise of the Council of Europe and co-operate closely with it." 84

\footnotetext{
${ }^{80}$ Council of Europe and the European Union, Memorandum of Understanding between the Council of Europe and the European Union, paragraph 23.

${ }^{81}$ Ibid, paragraph 23-24.

${ }^{82}$ Committee of Ministers, 'Report on co-operation between the Council of Europe and the European Union' 12 May 2017, CM(2017)28-final.

${ }^{83}$ Council of the European Union, Conclusions on Fundamental Rights and the Rule of Law, June 2013.

${ }^{84}$ In its reply to Parliamentary Assembly Recommendation 2027 (2013).
} 
The Council of Europe welcomed the European Commission's understanding of the Framework as a complementary component to "all the existing mechanisms already in place at the level of the Council of Europe to protect the Rule of Law." 85 During the assessment phase of the Rule of Law Framework, the Commission may refer to the expertise of different parties where necessary, including the Council of Europe's Venice Commission. The Communication from the Commission on the Rule of Law Framework noted that the European Commission "will as a rule and in appropriate cases seek the advice of the Council of Europe and/or its Venice Commission." 86 The Commission reiterated and developed these ideas in two further communications issued in April ${ }^{87}$ and July 2019. ${ }^{88}$ It notably committed to the "strengthen[ing] cooperation with the Council of Europe, including the Venice Commission and GRECO, and explore further support to it in relation to EU priorities on the rule of law." 89

One might be tempted to argue that the more instruments and institutions there are to protect and promote the Rule of Law, the better for the purpose of ensuring that governments act in conformity with the Rule of Law. In October 2016, the European Parliament endorsed the Committee on Civil Liberties, Justice and Home Affair's legislative initiative report calling for the establishment of a new binding mechanism to monitor the Rule of Law, democracy and the fundamental rights' situation in Europe. The mechanism aims to ensure compliance with EU values through preventative, corrective and sanctioning measures. It is composed of four core elements: an annual European report to identify possible breaches (the European DRF report) which includes country-specific and general recommendations, an annual interparliamentary debate on the abovementioned report, proposals to remedy possible risks and violations as provided for by the relevant treaties, and lastly a monitoring cycle (DRF policy cycle) within the main EU institutions. Whilst the Commission expressed its support for the Parliament's objective, particularly the fostering of an inter-parliamentary dialogue on democracy, the Rule of Law and fundamental rights, it was more sceptical of the need and feasibility of an annual independent expert report on the Rule of Law. ${ }^{90}$

In addition to the Commission's hesitant appraisal of the EP's initiative, one must not ignore the genuine risk of a duplication of standards and actors, which may lead to serious inconsistencies and forum-shopping practices, an outcome that cannot be seen to be in the interest of either citizens or governments. As a means of avoiding

\footnotetext{
${ }^{85}$ Communication from the Commission to the European Parliament and the Council a New EU Framework to Strengthen the Rule of Law, COM/2014/0158 final of 11 March 2014, page 6.

${ }^{86}$ Ibid, page 9.

${ }^{87}$ 'Further Strengthening the Rule of Law within the Union - State of play and possible next steps' $\operatorname{COM}(2019) 163$ final of 3 April 2019.

${ }^{88}$ 'Strengthening the rule of law within the Union - A blueprint for action' $\operatorname{COM}(2019) 343$ final of 17 July 2019.

${ }^{89}$ Ibid, page 8 .

${ }^{90}$ Communication from the Commission to the European Parliament and the Council a New EU Framework to Strengthen the Rule of Law supra (note 87) page 6.
} 
such overlaps, the Council and the relevant European institutions abide by a general policy of cooperation such as exemplified by the European Commission and the CEPEJ, where the EU justice scoreboard relies upon the information provided by the CEPEJ, thereby avoiding any potential duplication and confirming the CEPEJ's status as a common reference point for justice evaluations. The DRF report similarly refers to "cooperation envisaged with the Council of Europe and other bodies." ${ }^{.11}$ In April 2019, the Parliamentary Assembly examined 'the establishment of a European Union mechanism on democracy, the rule of law and fundamental rights'. The Assembly voiced concern "that, in the long run, the variety of the rule of law related initiatives involving different European Union institutions may jeopardise both the Memorandum of Understanding's declared objective of ensuring the coherence of the standard-setting system in Europe, and the complementarity and efficiency of mechanisms in upholding the shared values of human rights, democracy and the rule of law which exist within the two institutions with regard to States which are members of both the Council of Europe and the European Union. ${ }^{, 2}$ The Assembly invited the European Union, in the framework of its existing procedures and its initiatives to ensure compliance with the values guaranteed in Article 2 of the Treaty on European Union, to:

- "support the effective application of benchmarks at European level, using the Council of Europe's 'rule of law standards', including the case law of the European Court of Human Rights, relevant recommendations of the Committee of Ministers, standards and opinions of the Venice Commission (including the 'Rule of Law Checklist') and recommendations, opinions and/or conclusions of other relevant Council of Europe bodies;

- use the available reports, opinions or recommendations of the Council of Europe's advisory or monitoring bodies, not only citing them as references in the documents produced by the European Union bodies, but taking into account the conclusions of these bodies in the assessment by the institutions of the European Union to determine whether a rule of law issue has arisen, as well as to guide proposals for any action to be taken;

- when assessing whether a rule of law deficiency has been remedied or has ceased to exist, liaise with the relevant Council of Europe bodies which issued the opinion or the recommendation to ensure consistency of views and conclusions. The initiative for political action in the event of alleged non-compliance with the European Union legal framework would remain with the European Union, with the Council of Europe offering legal and technical assessment in accordance with its monitoring or advisory bodies' competences;

- provide for safeguards in all mechanisms of the European Union to ensure that the assessment or action of the European Union will not affect existing procedures arising from Council of Europe advisory or monitoring mechanisms, along

\footnotetext{
${ }^{91}$ Ibid, page 7.

${ }^{92}$ Parliamentary Assembly, Establishment of a European Union Mechanism on Democracy, the Rule of Law and Fundamental Rights, Recommendation 2151 (2019), paragraph 7.
} 
similar lines to Article 53 of the Charter of Fundamental Rights of the European Union., ${ }^{, 93}$

With the next Commission, headed by Ursula von der Leyen due to take office at the end of 2019, Brussels has indicated that it intends to remain tough on the Rule of Law. In turn, the joint Belgian-German proposal, to subject all EU countries to an annual Rule of Law monitoring procedure has been favourably received by the Commission $^{94}$ and presents an excellent opportunity to establish new modes of collaboration and mutual-reinforcement between the Council of Europe and the European Union.

\section{Concluding Remarks}

The Council of Europe is neither rich nor particularly powerful. In 2019, the Council of Europe's budget totalled some $€ 437$ million. If divided between every single European citizen, this would amount to less than $€ 2$ per person, as much as a cup of coffee, which leads one to conclude that the Council is, on the balance of probabilities, a worthwhile investment.

First and foremost, the Council does not embody one particular political or governmental vision but draws upon the experiences, skills and knowhow of the national experts from 47 member States. Somehow, almost paradoxically, its comparative weakness as a political actor provides legitimacy in relation to the formulation of legal standards and recommendations and thus the Council is perceived as a more neutral political actor than for example, the European Union.

These attributes allow the Council to engage in a dialogue with its member States and to openly and constructively address emerging issues in order to avoid division. The Council's main working asset is its credibility and trust acquired through 70 years of successful cooperation. Indeed, it this deep cooperation between the Council of Europe and the EU which is necessary for the promotion and safeguarding of the Rule of Law. In order to properly function, both institutions require that their respective members share a common understanding of the values and principles which define the Rule of Law.

Various forms of successful cooperation on Rule of Law related issues are already taking place, including most notably the Venice Commission, Group of States against Corruption (GRECO), the CEPEJ and the work undertaken by the Human Rights Commissioner. Thus, any initiative to set up new Rule of Law related mechanisms within the EU should take into account the existing Council of Europe

\footnotetext{
${ }^{93}$ Parliamentary Assembly, Establishment of a European Union Mechanism on Democracy, the Rule of Law and Fundamental Rights, Resolution 2273 (2019), paragraph 16.1-16.4.

${ }^{94}$ European Commission Press Release, "Strengthening the Rule of Law through increased awareness, an annual monitoring cycle and more effective enforcement" (17 July 2019) https://ec.europa. eu/commission/presscorner/detail/en/IP_19_4169.
} 
instruments, in particular the Rule of Law Checklist. The fact that the Council's mechanisms are not limited to the EU-28 but practically cover the entire continent should not be regarded as a weakness but rather as a strength, as this provides for a more consistent approach to the Rule of Law.

The existing cooperative relationship between the Council and the EU should be strengthened by increasing the EU's contribution in order to ensure that the conclusions and recommendations of the Council's Rule of Law mechanisms are implemented by the EU's Member States. Secondly, the EU could join a number of selected mechanisms as a full member, such as GRECO $^{95}$ or the Venice Commission and thereby fully utilise the Council's instruments with a view of better safeguarding the Rule of Law within the EU, particularly in situations where the EU's competences are limited. Lastly, for the purpose of upholding the Rule of Law within Europe, it is of the upmost importance that the EU finally makes good on its promises and accedes to the ECHR.

The resilience of the Polish democracy must not be underestimated. Poland has one of the oldest democratic traditions in Europe with a written constitution dating back to the 3 May 1791, which is widely considered to be Europe's first codified constitution (and the world's second). According to King Stanisław August Poniatowski, it was "founded principally on those of England and the United States of America, but avoiding the faults and errors of both, and adapted as much as possible to the local and particular circumstances of the country."96

Whereas the transition towards democracy was a peaceful one for most countries behind the iron curtain, the price paid by civil society in Romania was a particularly high one. It is perhaps for this reason that the Romanian people have taken to the streets in their tens of thousands to protest against the Rule of Law backsliding of their country. Prompted by the largest street protests since the fall of Communism, President Klaus Iohannis decided to couple the recent European elections with a referendum on the controversial justice reforms. Romanian's were asked: “1). Do you agree with banning amnesty and pardon for corruption offenses? 2). Do you agree with banning the adoption by the Government of emergency ordinances in the area of crimes, punishment and judiciary organizations, and with extending the right to challenge ordinances directly at the Constitutional Court." An overwhelming 84\% answered in the affirmative. If anything, the situation in Romania demonstrates the importance of a strong, engaged and informed civil society for the protection of the Rule of Law and democratic values.

Whatever constitution a country chooses to adopt, checks and balances between State powers remain crucial for every democracy. A modern constitution has to guarantee both effective democratic decision-making according to the majorities' will and the protection of individuals and minorities against the dangers of a

\footnotetext{
${ }^{95}$ On 10 July 2019, the EU has been granted observer status with GRECO, see Committee of Ministers' decision CM/Del/Dec(2019)1351bis/11.1.

${ }^{96}$ Barentine (2015), p. 394.
} 
majoritarian rule. ${ }^{97}$ In that context, the role of an independent judiciary cannot be overstated. Their work reinforces democracy and promotes the Rule of Law by guaranteeing free elections, clearing the political space for the freedom of association, expression and religion, combating discrimination, and enabling political change. Therefore, whilst Poland and Romania are free to reform their judicial systems, they should do so in a manner which is consistent with the Rule of Law and does not threaten the independence of the judiciary, the separation of powers, the principle of res judicata or legal certainty.

\section{References}

Barentine CJ (2015) The lost constellations: a history of obsolete, extinct, or forgotten star lore. Springer International Publishing, New York

Carrera S, Guild E, Hernanz N (2013) The triangular relationship between fundamental rights, democracy and the rule of law in the EU. Available via https://www.ceps.eu/ceps-publications/ triangular-relationship-between-fundamental-rights-democracy-and-rule-law-eu-towards-eu/.

Accessed 21 Aug 2019

Drzemczewski A (2018) European Commission for democracy through law (Venice Commission). Human Rights Law J 37:184-198

Evans P, Silk P (2013) The Parliamentary assembly - practice and procedure, 11th edn. Council of Europe, Strasbourg

Gardner D (6 April 2017) A breach between Turkey and the EU that suits both sides, Financial Times. p. 6

Grimm D (2016) Europa ja - aber welches? Zur Verfassung der europäischen Demokratie. Verlag C.H. Beck, Munich

Huber P (2016) The principle of proportionality. In: Schroeder W (ed) Strengthening the rule of law in Europe, 1st edn. Hart Publishing, Oxford, p 111

Lübbe-Wolff G (2019) 'Richterwahlen in der Schweiz: Wo liegt das Problem?' VerfBlog, Available via https://verfassungsblog.de/richterwahlen-in-der-schweiz-wo-liegt-das-problem/. Accessed 26 Aug 2019

Polakiewicz J, Sandvig J (2016) The Council of Europe and the rule of law. In: Schroeder W (ed) Strengthening the rule of law in Europe, 1st edn. Hart Publishing, Oxford, pp 115-134

Steiner E (2016) The rule of law in the jurisprudence of the European Court of Human Rights. In: Schroeder W (ed) Strengthening the rule of law in Europe, 1st edn. Hart Publishing, Oxford, p 154

Jörg Polakiewicz is a Professor at the Europainstitut of the University of Saarbrücken and Director of Legal Advice and Public International Law (Legal Adviser), Council of Europe. This contribution was written in a strictly personal capacity and does not necessarily reflect the official position of the Council of Europe.

\footnotetext{
${ }^{97}$ Huber (2016), p. 111.
} 
Julia Katharina Kirchmayr holds a Master of Laws from the University of Edinburgh and is a Legal Officer at the European Commission. This contribution was written in a strictly personal capacity and does not necessarily reflect the official position of the European Commission.

Open Access This chapter is licensed under the terms of the Creative Commons Attribution 4.0 International License (http://creativecommons.org/licenses/by/4.0/), which permits use, sharing, adaptation, distribution and reproduction in any medium or format, as long as you give appropriate credit to the original author(s) and the source, provide a link to the Creative Commons license and indicate if changes were made.

The images or other third party material in this chapter are included in the chapter's Creative Commons license, unless indicated otherwise in a credit line to the material. If material is not included in the chapter's Creative Commons license and your intended use is not permitted by statutory regulation or exceeds the permitted use, you will need to obtain permission directly from the copyright holder. 